\title{
Chemical and Numerical Taxonomy of Strains Received as Gordona aurantiaca
}

\author{
By M. GOODFELLOW, P. A. B. ORLEAN, M. D. COLLINS \\ AND L. ALSHAMAONY \\ Department of Microbiology, The Medical School, University of \\ Newcastle upon Tyne, Newcastle upon Tyne NE1 $7 R U$ \\ AND D. E. MINNIKIN \\ Department of Organic Chemistry, University of Newcastle upon Tyne
}

(Received 17 May 1978)

\begin{abstract}
Eight strains of Gordona aurantiaca, 89 representatives of the genera Mycobacterium, Nocardia and Rhodococcus and a single strain of Brevibacterium linens were the subject of numerical phenetic analyses using 92 unit characters. The $G$. aurantiaca cluster was robust in different numerical analyses and equivalent in rank to the genera Mycobacterium, Nocardia and Rhodococcus. The presence of a characteristic mycolic acid and completely unsaturated menaquinones distinguished $G$. aurantiaca strains from mycobacteria, nocardiae and rhodococci. The congruence between the numerical and phenetic data indicate that $G$. aurantiaca strains form a distinct taxon resembling other mycolic acid-containing taxa in wall, fatty acid and polar lipid composition. Since the genus Gordona is no longer valid, a new niche is needed for $G$. aurantiaca.
\end{abstract}

\section{INTRODUCTION}

The genus Gordona was created for slightly acid-fast organisms found in soil and associated with pulmonary disease (Tsukamura, 1971). As originally proposed, the genus contained Gordona bronchialis, Gordona rubra and Gordona terrae but an additional species, Gordona aurantiaca, was added (Tsukamura \& Mizuno, 1971) for strains from sputa of patients with cavitary pulmonary tuberculosis or bronchiectasis. Subsequently, Tsukamura $(1973,1974,1975)$ suggested that some rhodochrous strains should be classified in the genus and proposed three new species: Gordona rhodochroa, Gordona rosea and Gordona rubropertincta (syn. G. rubra). Strains provisionally classified as Nocardia rubra were added as Gordona lentifragmenta (Tsukamura et al., 1975).

Early phenetic studies indicated the equivocal position of Gordona aurantiaca in the genus Gordona. Gordona aurantiaca strains were found to be only loosely associated with clusters containing other gordonae and showed almost equal similarity to fast-growing mycobacteria (Tsukamura, 1974, 1975). In a subsequent study (Tsukamura et al., 1975), G. aurantiaca strains were recovered in a distinct cluster equivalent to those containing fast-growing mycobacteria, nocardiae and other gordonae, respectively, and were distinguished from other gordonae by their $\beta$-galactosidase activity and inability to reduce nitrate. The genus Rhodococcus was proposed (Goodfellow \& Alderson, 1977) for strains classified either in the genus Gordona or as members of the 'rhodochrous' complex (Bousfield \& Goodfellow, 1976). The type strain of $G$. aurantiaca studied by Goodfellow \& Alderson (1977) was only loosely associated with the Rhodococcus cluster and it was concluded that additional comparative studies were required to determine the relationships between $G$. aurantiaca and other nocardioform taxa. The assignment of the other Gordona species, including the 
type species G. bronchialis, to Rhodococcus leaves G. aurantiaca as a taxon in search of a genus.

In the present study $G$. aurantiaca strains were compared with representatives of the genera Mycobacterium, Nocardia and Rhodococcus using numerical and chemotaxonomic methods.

\section{METHODS}

Strains. Eight strains of Gordona aurantiaca, 10 fast-growing mycobacteria, 13 nocardiae, 65 rhodococci and strains of Brevibacterium linens and Corynebacterium equi were included in the numerical survey (Table 1). Detailed histories of most of these strains have been given previously (Goodfellow, 1971; Goodfellow et al., 1972; Goodfellow \& Alderson, 1977). All of the test strains were maintained on glucose yeast extract agar at room temperature (Gordon \& Mihm, 1962).

Collection and coding of data. Strains of Gordona aurantiaca (м290 to м296, N663), Brevibacterium linens (c40), Corynebacterium equi (c36) and Rhodococcus coprophilus ( $\mathrm{N} 744)$ were screened for 92 unit characters and the data were added to those previously collected on the remaining strains (Goodfellow \& Alderson, 1977).

Computer analysis. Data were analysed using the Clustan 1A program of Wishart (1968) on an IBM370/168 computer using both the simple matching coefficient $\left(S_{S M}\right)$ (Sokal \& Michener, 1958), which includes positive and negative similarities, and the Jaccard coefficient $\left(S_{J}\right)$ (Sneath, 1957), which excludes negative matches. Clustering was done using both the single linkage and unweighted average linkage (UPGMA) algorithms (Sneath \& Sokal, 1973). Data from the $S_{S M}$ and UPGMA analyses were used to prepare a sorted shaded diagram (Fig. 1). Vigour and pattern statistics were calculated (Wishart, 1968) and the data were sorted using the UPGMA algorithm. Mean intragroup and intergroup similarity values were calculated for the clusters defined in the $S_{S M}$ and average linkage analysis.

Lipid analyses. The G. aurantiaca strains were grown in shake culture at $30^{\circ} \mathrm{C}$ for 3 to $5 \mathrm{~d}$ in modified Sauton's medium (Mordarska et al., 1972) supplemented with vitamin $\mathbf{B}_{1}\left(50 \mu \mathrm{g} \mathrm{ml}^{-1}\right)$. Cultures were checked for purity at maximum growth, killed by shaking with formalin $(1 \%, \mathrm{v} / \mathrm{v})$, separated by centrifugation, washed with distilled water and freeze-dried. Dried cells of Mycobacterium avium D4, Rhodococcus (Gordona) bronchialis $\mathrm{N} 654$, Rhodococcus corallinus (Gordona rubra) $\mathrm{N} 655$ and Rhodococcus (Gordona) terrae N656 (Minnikin et al., 1975; Alshamaony et al., 1976b) were used as standards for the analysis of longchain components.

Freeze-dried bacteria ( 50 to $100 \mathrm{mg}$ ) were degraded by acid methanolysis and hexane extracts were examined for long-chain components by thin-layer chromatography (t.l.c.) as described previously (Minnikin et al., 1975) using Merck silica gel $\mathrm{H}(0.5 \mathrm{~mm}$ layers) and a developing mixture of petroleum ether (b.p. 60 to $\left.80^{\circ} \mathrm{C}\right) /$ diethyl ether $(85: 15, \mathrm{v} / \mathrm{v})$. Long-chain components were isolated by preparative t.l.c. on layers $(1 \mathrm{~mm})$ of Merck silica gel $\mathrm{PF}_{254+366}$, separated bands being detected with ultraviolet light $(366 \mathrm{~nm})$.

Long-chain fatty acid methyl esters were analysed using a Perkin-Elmer F11 gas chromatograph fitted with stainless steel columns $(200 \times 0.4 \mathrm{~cm})$ packed with $3 \%$ ASI 50 cyano propyl silicone (Silar $5 \mathrm{CP})$ on 80 to 100 mesh Gas Chrom Q (Applied Science Laboratories) or $2.5 \%$ OV-1 methyl silicone on 80 to 100 mesh Chromosorb G AW-DMCS (Phase Separations) using nitrogen $\left(40 \mathrm{ml} \mathrm{min}^{-1}\right)$ as carrier gas at isothermal oven temperatures of 165 and $180^{\circ} \mathrm{C}$, respectively. Pyrolysis gas chromatography of mycolic acid methyl esters was done using a short column $(50 \times 0.4 \mathrm{~cm})$ of the OV-1 packing material with temperature programming at $6{ }^{\circ} \mathrm{C} \mathrm{min}^{-1}$ from 120 to $300{ }^{\circ} \mathrm{C}$ and the injection heater set at $320^{\circ} \mathrm{C}$.

The isoprenoid quinones were extracted and analysed as described by Collins et al. (1977). Mass spectra of the purified menaquinones and mycolic esters were taken on an AEI MS9 instrument using a direct insertion probe, an ionizing voltage of $70 \mathrm{eV}$ and a temperature range of 190 to $220^{\circ} \mathrm{C}$.

Partial mass spectra of the menaquinones have been deposited with the British Library Lending Division, Boston Spa, Yorkshire LS23 7BQ, as Supplementary Publication No. SUP 28008 (3 pages). Copies may be obtained from the BLLD on demand. Where possible, requests should be accompanied by prepaid coupons (held by many university and technical libraries and by the British Council).

\section{RESULTS}

Clustering of the strains using the $S_{S M}$ coefficient and the average linkage algorithm

The rhodococci, mycobacteria and nocardiae grouped into three clusters (1, 2 and 3, respectively) defined at the 75 to $80 \%$ similarity level (S level) (Fig. 1). The Gordona aurantiaca strains were recovered in cluster 4 , which was defined at the $87 \% \mathrm{~S}$ level. The single strain of Brevibacterium linens, c40, fell outside the four main clusters. The mean 


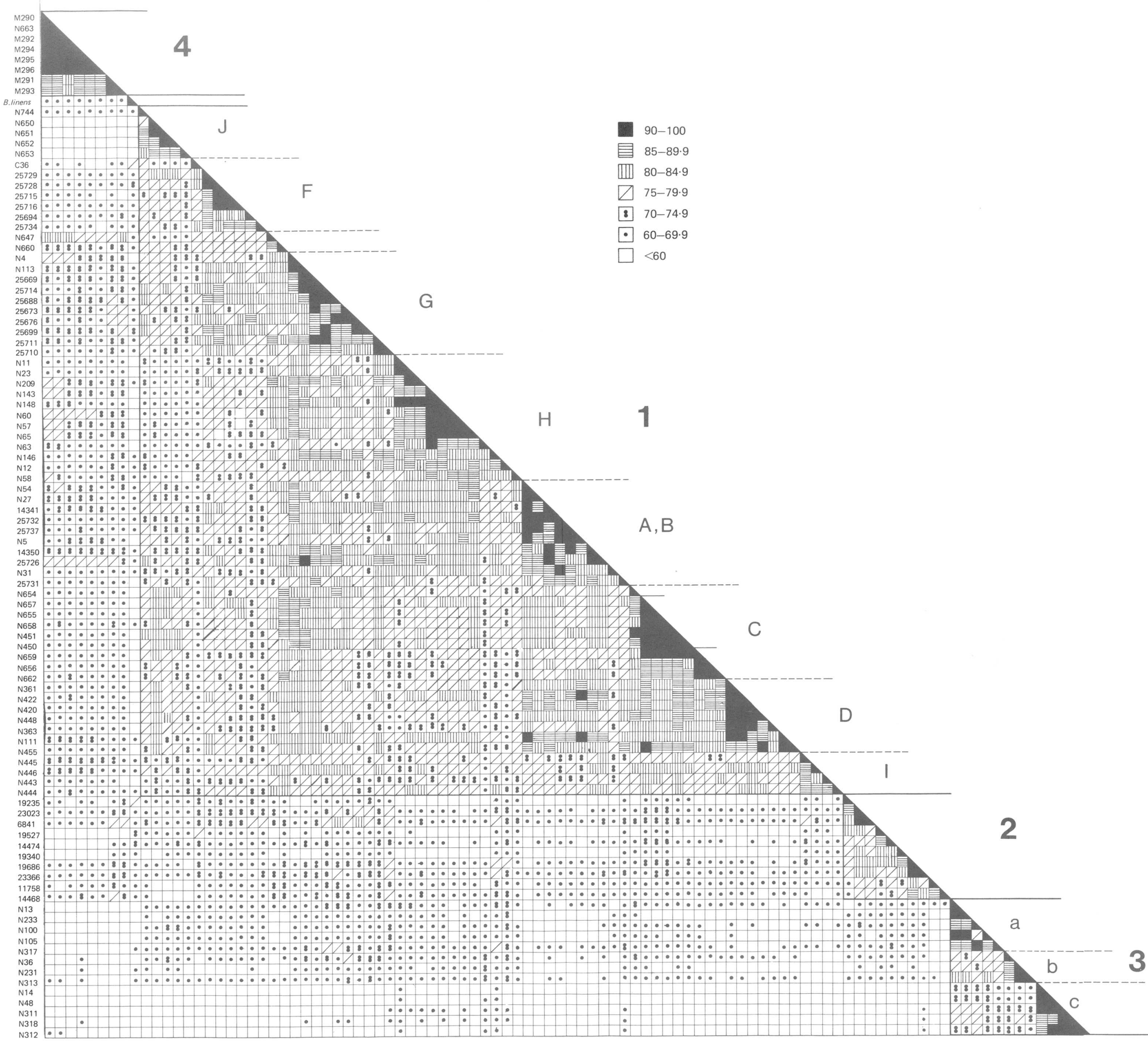

Fig. 1. Shaded diagram based on the analysis of the 98 test strains and 92 unit characters

(Facing p. 58) using the $S_{S M}$ coefficient and the average linkage algorithm. 
Table 1. Designation and source of strains assigned to clusters 1, 2, 3 and 4 in the $S_{S M}, U P G M A$ analysis

$\begin{array}{cl} & \text { (a) Strains assigned to subcluster 1A } \\ \mathrm{N} 5 & \text { Rhodococcus rhodochrous; NCIB 9701 } \\ \mathrm{N} 27 & \text { R. rhodochrous; NCIB 9160 } \\ \mathrm{N} 31 & \text { R. rhodochrous; R. E. Gordon (R.E.G.), } \\ & \text { Rutgers University, U.S.A., w21 } \\ \text { * } 54 & \text { R. rhodochrous; ATCC 13808 } \\ \text { R10 } & \text { R. rhodochrous; ATCC } 14341 \\ \text { R15 } & \text { R. rhodochrous; ATCC } 14350 \\ \text { R68 } & \text { R. rhodochrous; ATCC 25726 } \\ \text { R73 } & \text { R. rhodochrous; ATCC 25731 } \\ \text { R74 } & \text { R. rhodochrous; ATCC 25732 } \\ \text { R79 } & \text { R. rhodochrous; ATCC } 25737\end{array}$

(b) Strains assigned to subcluster 1C

*N654 Rhodococcus bronchialis; NCTC 10667

N450 Rhodococcus corallinus, R. Bönicke,

Institut für Experimentelle Biologie und Medizin, Borstel, West Germany, SN5303

N451

* N655

*N657

N658

*N656

* 659

${ }^{*} \mathrm{~N} 662$

$R$. corallinus; R. Bönicke, $\mathrm{SN} 5302$

$R$. corallinus; NCTC 10668

$R$. corallinus; NCTC 10668

$R$. corallinus; ATCC 60004

Rhodococcus terrae; NCTC 10669

$R$. terrae; NCTC 10669

R. terrae; H. Mordarska, Hirszfeld, Institute, Wrocław, Poland, T6

(c) Strains assigned to subcluster 1D

N111 Rhodococcus rhodochrous; R.E.G., 562

*N361 Rhodococcus ruber; M. Tsukamura, Chuba Chest Hospital, Obu, Aichi-ken 474, Japan, M-1

N363 R. ruber; M. Tsukamura, M-192

N420 R. ruber; A. Tacquet, Pasteur Institute, Lille, 906

N422 R. ruber; A. Tacquet, 107

N448 R. ruber; R. Bönicke, SN5104

$\mathrm{N} 455 \quad R$. ruber; R. Bönicke, SN5203

(d) Strains assigned to subcluster $1 \mathrm{~F}$

${ }^{*} \mathrm{C} 36 \quad$ Corynebacterium equi; NCTC 1621

R39 Rhodococcus equi; ATCC 25694

R59 R. equi; ATCC 25715

R60 R. equi; ATCC 25716

$\mathrm{R} 70 \quad R$. equi; $\mathrm{ATCC} 25728$

R71 R. equi; ATCC 25729

R76 R. equi; ATCC 25734

(e) Strains assigned to subcluster $1 \mathrm{G}$

*N4 Rhodococcus rubropertinctus; NCIB 9664

N113 R. rubropertinctus; V. B. D. Skerman, Queensland University, Brisbane, Australia, 134

R17 R. rubropertinctus; ATCC 25669

R21 R. rubropertinctus; ATCC 25673

R24 R. rubropertinctus; ATCC 25676

$\mathrm{R} 34 \quad R$. rubropertinctus; ATCC 25688

R43 R. rubropertinctus; ATCC 25699

R55 R. rubropertinctus; ATCC 25710

R56 R. rubropertinctus; ATCC 25711

R58 R. rubropertinctus; ATCC 25714

( $f$ ) Strains assigned to subcluster $1 \mathrm{H}$

${ }^{*} \mathrm{~N} 11$

$\mathrm{N} 12$

$\mathrm{N} 23$

N57

N58

R. erythropolis; NCIB 9159

$R$. erythropolis; R.E.G., $1293 \mathrm{~s}$

R. erythropolis; R.E.G., 1257

\author{
N60 R. erythropolis; R.E.G., 1293R \\ N63 R. erythropolis; R.E.G., 463 \\ N65 R. erythropolis; R.E.G., A7698 \\ N143 R. erythropolis; M. Turner, Nottingham \\ University, 29 \\ N148 R. erythropolis; M. Turner, 83 \\ N209 R. erythropolis; J. E. Thiemann, Lepetit \\ SpA, Milan, Italy, A2 \\ N146 Rhodococcus rubropertinctus; M. Turner, \\ 39
}

N443

(g) Strains assigned to subcluster 1I

N444

*N445

N446

N650

N651

$\mathrm{N} 652$

$\mathrm{N} 653$

${ }^{*}$ N744

N647

${ }^{*}$ N660

*M12

* M89

${ }^{*} \mathrm{M} 158$

${ }^{*} \mathrm{M} 3$

* M93

${ }^{*} \mathrm{M} 17$

* $\mathrm{M6}$

* M98

${ }^{*}$ M101

${ }^{*} \mathrm{M} 11$

N13

N100

N105

N233

${ }^{*}$ N317

N14

$\mathrm{N} 48$

N311

N312

*N318

*N36

N231

N313

* M290

Gordona aurantiaca;

G. aurantiaca; M. Tsukamura, 3477, 4409, M296 4465, 7972, 7973, 8128

*N663 G. aurantiaca; NCTC 10741

c40

(m) Strain not assigned to any cluster Brevibacterium linens; ATCC 9174

* Type strains.

M, N, R, Laboratory numbers; ATCC, American Type Culture Collection; CCM, Czechoslovak Collection of Microorganisms; NCIB, National Collection of Industrial Bacteria; NCTC, National Collection of Type Cultures. 
Table 2. Percentage intergroup similarities between the Gordona aurantiaca cluster and the other clusters and subclusters obtained from the $S_{S M}$, average linkage analysis

\begin{tabular}{clc} 
Phenon & \multicolumn{1}{c}{ Taxon } & $\begin{array}{c}\text { Percentage } \\
\text { similarity to } \\
\text { G. aurantiaca }\end{array}$ \\
1 & Rhodococcus & $68 \cdot 1$ \\
2 & Mycobacterium & $62 \cdot 9$ \\
3 & Nocardia & $54 \cdot 0$ \\
IG & Rhodococcus rubropertinctus & $71 \cdot 6$ \\
1A & Rhodococcus rhodochrous & $70 \cdot 7$ \\
1H & Rhodococcus erythropolis & $70 \cdot 4$ \\
1I & Rhodococcus rhodnii & $68 \cdot 1$ \\
& Rhodococcus bronchialis & \\
IC & Rhodococcus corallinus & $67 \cdot 4$ \\
& Rhodococcus terrae & $66 \cdot 1$ \\
ID & Rhodococcus ruber & $63 \cdot 5$ \\
1F & Rhodococcus equi & $58 \cdot 3$ \\
IJ & Rhodococcus coprophilus & $59 \cdot 5$ \\
3b & Nocardia caviae & $55 \cdot 4$ \\
3c & Nocardia brasiliensis & $48 \cdot 1$ \\
3a & Nocardia asteroides & $69 \cdot 0$ \\
\hline- & Brevibacterium linens &
\end{tabular}

intragroup S value for the G. aurantiaca cluster was $91.5 \%$; the mean intergroup similarities between it and the other clusters are shown in Table 2. Mean intragroup $S$ values for the Rhodococcus cluster and its subclusters, the Mycobacterium cluster and the Nocardia cluster were determined by Goodfellow \& Alderson (1977).

Cluster 1 (Rhodococcus) was divided into nine subclusters of essentially similar composition to those obtained by Goodfellow \& Alderson (1977) who included 80 additional rhodococci in their analyses. These authors attributed the occurrence of Rhodococcus ruber strains in two subclusters, $1 \mathrm{D}$ and $1 \mathrm{E}$, to sampling error. The strains of subcluster $1 \mathrm{E}$ were not, therefore, included in the present analysis. The single representative of Goodfellow \& Alderson's (1977) subcluster 1B (N31) fell within subcluster 1A, a result in good accord with DNA:DNA reassociation data (Mordarski et al., 1977). As expected the type strains of Corynebacterium equi (c36) and Rhodococcus coprophilus were recovered in the subclusters bearing these names (1F and $1 \mathrm{~J}$, respectively).

\section{Clustering of the strains using other coefficients and clustering algorithms}

The four major clusters were recovered in the three other analyses. Use of the $S_{J}$ coefficient had a marginal effect on the composition of the Rhodococcus subclusters but the main clusters were well separated. With the exception of subcluster 1A (Rhodococcus rhodochrous strains), which was ill-defined, use of the single linkage algorithm had little effect on the composition of subclusters, which remained distinct.

The pattern coefficient seeks to allow for differences in growth rates, incubation periods and similar factors which might contribute to overall dissimilarity between two strains. It excludes the vigour component $\left(D_{V}\right)$, which expresses the difference in total metabolic activity of two strains, from the total difference between the strains, leaving clusters defined on the basis of pattern difference $\left(D_{P}\right)$ (Sneath, 1968). The removal of the vigour component from total dissimilarities did not have any effect on the distribution of strains to the four main clusters and only marginally affected the clustering of the rhodococci, members of subcluster 1D (Rhodococcus ruber) falling within subcluster 1C (Rhodococcus bronchialis, Rhodococcus corallinus, Rhodococcus terrae). Though well separated from the other three clusters in the pattern analysis, the Gordona aurantiaca cluster was joined by the marker strain Mycobacterium borstelense (M89) and less strongly by Brevibacterium linens (c40). 
Table 3. Percentage frequencies of positive characters found in the major clusters

\begin{tabular}{|c|c|c|c|}
\hline \multicolumn{4}{|c|}{ Cluster } \\
\hline 1 & 2 & 3 & 4 \\
\hline $\begin{array}{l}\text { Rhodococcus } \\
(66)^{*}\end{array}$ & $\begin{array}{l}\text { Myco- } \\
\text { bacterium } \\
(10)\end{array}$ & $\begin{array}{l}\text { Nocardia } \\
\text { (13) }\end{array}$ & $\begin{array}{c}\text { Gordona } \\
\text { aurantiaca } \\
\text { (8) }\end{array}$ \\
\hline
\end{tabular}

Staining and colony morphology:

Strongly acid-fast

Aerial hyphae, sparse

Aerial hyphae, moderate

Aerial hyphae, abundant

Colonies white

$100 \quad 0 \quad 25$

0
20

0
0

$\begin{array}{ll}0 & 85\end{array}$

1
0

17

Colonies pink, red, orange

0

70

10

Colonies yellow

83
0

Diffusible exopigment

20
0

Elevation convex

0

Elevation irregular

Margin entire

70

8

Margin filamentous

Mycelium formed

65

22

97

0
100

100
0

100

Degradation of :

Adenine

Allantoin, weak

Allantoin, strong

Casein

Elastin

Hypoxanthine

0
0

85
77

23

77

0
100

8

92

0

92

100

0

0
0

100

0

0
0

100

0

100

0
0

Tween 20

Tween 40

Tween 60

Tyrosine

Urea, weak

Urea, strong

Xanthine

$\begin{array}{rrr}0 & 0 & 0 \\ 0 & 100 & 63 \\ 0 & 23 & 50 \\ 0 & 38 & 0 \\ 0 & 38 & 0 \\ 0 & 61 & 75 \\ 100 & 69 & 100 \\ 100 & 54 & 100 \\ 100 & 54 & 100 \\ 0 & 38 & 75 \\ 50 & 100 & 88 \\ 0 & 100 & 75 \\ 0 & 23 & 50\end{array}$

Growth on sole carbon source (at $1 \mathrm{~g}^{-1}$ ):
Adonitol
L-Arabinose
Cellobiose
D-Fructose
D-Galactose
Glycerol

98

46

82

49

0

50

50

0

80

10

70

0
15

0

92
38

100

Growth on sole carbon/nitrogen source:

Acetamide

Serine

Trimethylenediamine

30
20
60

46

38

Growth at:

$10^{\circ} \mathrm{C}$
$40{ }^{\circ} \mathrm{C}$
$45^{\circ} \mathrm{C}$
$50{ }^{\circ} \mathrm{C}$

100

Growth in the presence of:

$0.0001 \%(\mathrm{w} / \mathrm{v})$ Crystal violet

$100 \quad 23$

$0.001 \%(\mathrm{w} / \mathrm{v})$ Crystal violet

$0.01 \%(\mathrm{w} / \mathrm{v})$ Phenol

50

100

$0.1 \%(\mathrm{w} / \mathrm{v})$ Phenol

$0.02 \%(v / v)$ Phenylethanol

$0.03 \%$ (v/v) Phenylethanol

$0.01 \%(w / v)$ Sodium azide

$0.02 \%(w / v)$ Sodium azide

$5.0 \%(w / v)$ Sodium chloride

$7.0 \%$ (w/v) Sodium chloride

Susceptibility to $10 \mathrm{i} . \mathrm{u}$. penicillin

Enzyme activity:

Nitrate reduction

$m$-Nitrophenoloxidase

p-Nitrophenoloxidase

* Number of cultures analysed is given in parentheses.

90
0
0
100

100 
Table 4. Percentage frequencies of positive characters found in the Rhodococcus subclusters and the Gordona aurantiaca cluster

\section{Character}

Staining and colony morphology:

Strongly acid-fast

Aerial hyphae, sparse

Aerial hyphae, moderate

Aerial hyphae, abundant

Colonies white

Colonies pink, red, orange

Elevation convex

Elevation irregular

Margin entire

Margin filamentous

Mycelium formed

Degradation of :

Adenine

Allantoin, weak

Allantoin, strong

Hypoxanthine

Tween 40

Tween 60

Tyrosine

Urea, weak

Urea, strong

Xanthine

Growth on sole carbon source

(at $1 \mathrm{~g} \mathrm{1}^{-1}$ ):

Adonitol

L-Arabinose

Cellobiose

D-Fructose

Growth on sole carbon/nitrogen source:

Acetamide

Serine

Growth at:

$10{ }^{\circ} \mathrm{C}$

$40{ }^{\circ} \mathrm{C}$

$45^{\circ} \mathrm{C}$

$50^{\circ} \mathrm{C}$

Growth in the presence of: $0.0001 \%(\mathrm{w} / \mathrm{v})$ Crystal violet $0.001 \%(\mathrm{w} / \mathrm{v})$ Crystal violet $0.1 \%(\mathrm{w} / \mathrm{v})$ Phenol $0.03 \%(\mathrm{v} / \mathrm{v})$ Phenylethanol $0.01 \%$ (w/v) Sodium azide $0.02 \%(\mathrm{w} / \mathrm{v})$ Sodium azide $5.0 \%(w / v)$ Sodium chloride $7.0 \%(w / v)$ Sodium chloride

Susceptibility to 10 i.u. penicillin

Enzyme activity:

Nitrate reduction

$m$-Nitrophenoloxidase

$p$-Nitrophenoloxidase

Lipid LCN-A
Cluster/subcluster

$\begin{array}{lllllllll}1 \mathrm{~A}, \mathrm{~B} & 1 \mathrm{C} & 1 \mathrm{D} & 1 \mathrm{~F} & 1 \mathrm{G} & 1 \mathrm{H} & 1 \mathrm{I} & 1 \mathrm{~J} & 4 \\ (10)^{*} & (9) & (7) & (7) & (10) & (12) & (4) & (5) & (8)\end{array}$

$\begin{array}{rrrrrrrrr}0 & 0 & 0 & 0 & 0 & 0 & 0 & 0 & 25 \\ 10 & 0 & 29 & 0 & 10 & 33 & 0 & 20 & 0 \\ 0 & 0 & 14 & 0 & 0 & 0 & 0 & 0 & 0 \\ 0 & 0 & 0 & 0 & 0 & 0 & 25 & 0 & 0 \\ 0 & 0 & 14 & 29 & 30 & 50 & 25 & 0 & 100 \\ 100 & 100 & 86 & 71 & 70 & 50 & 75 & 100 & 0 \\ 90 & 56 & 100 & 100 & 100 & 83 & 100 & 20 & 100 \\ 0 & 0 & 0 & 0 & 0 & 17 & 0 & 80 & 0 \\ 90 & 33 & 29 & 100 & 100 & 100 & 100 & 0 & 100 \\ 10 & 11 & 71 & 0 & 0 & 0 & 0 & 100 & 0 \\ 100 & 44 & 100 & 86 & 100 & 100 & 100 & 80 & 0\end{array}$

$\begin{array}{rrrrrrrrr}70 & 0 & 14 & 86 & 0 & 92 & 0 & 20 & 0 \\ 0 & 0 & 0 & 0 & 10 & 92 & 0 & 0 & 63 \\ 0 & 0 & 0 & 0 & 0 & 0 & 0 & 0 & 50 \\ 0 & 0 & 0 & 0 & 0 & 0 & 0 & 0 & 75 \\ 100 & 100 & 100 & 100 & 100 & 100 & 50 & 100 & 100 \\ 100 & 100 & 100 & 100 & 100 & 100 & 100 & 80 & 100 \\ 90 & 0 & 86 & 0 & 0 & 75 & 100 & 0 & 75 \\ 60 & 88 & 71 & 100 & 100 & 92 & 100 & 80 & 88 \\ 50 & 11 & 0 & 71 & 90 & 92 & 50 & 0 & 75 \\ 0 & 0 & 0 & 0 & 0 & 0 & 0 & 0 & 50\end{array}$

$\begin{array}{rrrrrrrrr}0 & 0 & 0 & 0 & 0 & 0 & 0 & 0 & 0 \\ 0 & 0 & 0 & 0 & 0 & 8 & 25 & 0 & 0 \\ 0 & 0 & 0 & 0 & 0 & 0 & 0 & 0 & 38 \\ 100 & 100 & 100 & 71 & 100 & 100 & 100 & 100 & 100\end{array}$

$\begin{array}{rrrrrrrrr}40 & 33 & 86 & 48 & 40 & 67 & 100 & 0 & 88 \\ 0 & 0 & 0 & 0 & 0 & 0 & 0 & 0 & 100 \\ & & & & & & & & \\ 90 & 0 & 29 & 100 & 90 & 83 & 25 & 40 & 100 \\ 100 & 100 & 100 & 100 & 100 & 100 & 25 & 80 & 0 \\ 0 & 0 & 86 & 0 & 0 & 8 & 0 & 0 & 0 \\ 0 & 0 & 0 & 0 & 0 & 8 & 0 & 0 & 0\end{array}$

$\begin{array}{rrrrrrrrr}90 & 100 & 100 & 100 & 100 & 58 & 100 & 100 & 100 \\ 50 & 100 & 100 & 86 & 60 & 8 & 75 & 100 & 100 \\ 100 & 100 & 100 & 29 & 80 & 33 & 25 & 100 & 100 \\ 90 & 100 & 100 & 57 & 70 & 33 & 25 & 80 & 100 \\ 10 & 100 & 86 & 86 & 70 & 67 & 50 & 40 & 75 \\ 20 & 89 & 100 & 43 & 20 & 67 & 75 & 20 & 38 \\ 90 & 100 & 100 & 100 & 90 & 100 & 100 & 100 & 100 \\ 50 & 100 & 100 & 43 & 90 & 83 & 100 & 100 & 100 \\ 100 & 33 & 100 & 57 & 100 & 100 & 100 & 100 & 13\end{array}$

$\begin{array}{rrrrrrrrr}100 & 78 & 100 & 100 & 100 & 92 & 100 & 100 & 25 \\ 60 & 11 & 14 & 0 & 0 & 0 & 0 & 0 & 0 \\ 0 & 11 & 0 & 14 & 0 & 0 & 0 & 0 & 0 \\ 100 & 100 & 100 & 100 & 100 & 100 & 100 & 100 & 0\end{array}$

* Number of cultures analysed is given in parentheses.

None of the strains produced yellow colonies or diffusible pigment, degraded casein or elastin, utilized lactose or raffinose as sole carbon source, or utilized trimethylenediamine as sole carbon and nitrogen source. All degraded Tween 20, utilized sodium acetate as sole carbon source and grew in the presence of $0.01 \%(\mathrm{w} / \mathrm{v})$ phenol and $0.02 \%(\mathrm{w} / \mathrm{v})$ phenylethanol. 
Table 5. Distribution of characters with the greatest resolving power for differentiating Gordona aurantiaca, Rhodococcus, Mycobacterium and Nocardia

Results indicate the percentage frequency of positive characters.

\begin{tabular}{|c|c|c|c|c|}
\hline \multirow[b]{2}{*}{ Character } & \multicolumn{4}{|c|}{ Cluster } \\
\hline & $\begin{array}{c}1 \\
\text { Rhodococcus } \\
(66)^{*}\end{array}$ & $\begin{array}{c}2 \\
\text { Myco- } \\
\text { bacterium } \\
(10)\end{array}$ & $\begin{array}{c}3 \\
\text { Nocardia } \\
\text { (13) }\end{array}$ & $\begin{array}{c}4 \\
\text { Gordona } \\
\text { aurantiaca } \\
(8)\end{array}$ \\
\hline \multicolumn{5}{|l|}{ Staining and colony morphology: } \\
\hline Strongly acid-fast & 0 & 100 & 0 & 25 \\
\hline Mycelium formed & 97 & 0 & 100 & 0 \\
\hline Aerial hyphae formed & 20 & 0 & 92 & 0 \\
\hline Margin entire & 65 & 100 & 0 & 100 \\
\hline Colonies pink, red, orange & 83 & 10 & 77 & 0 \\
\hline Diffusible exopigment & 0 & 0 & 100 & 0 \\
\hline \multicolumn{5}{|c|}{ Growth on sole carbon source (at $1 \mathrm{~g} \mathrm{l}^{-1}$ ): } \\
\hline Ethanol & 97 & 20 & 0 & 100 \\
\hline Galactose & 3 & 10 & 38 & 100 \\
\hline Inulin & 90 & 80 & 8 & 0 \\
\hline Melezitose & 8 & 0 & 0 & 100 \\
\hline Xylose & 3 & 50 & 15 & 100 \\
\hline Growth at $40^{\circ} \mathrm{C}$ & 94 & 70 & 92 & 0 \\
\hline Growth in the presence of: & & & & \\
\hline $7.0 \%(w / v)$ Sodium chloride & 83 & 0 & 31 & 100 \\
\hline Susceptibility to 10 i.u. penicillin & 87 & 0 & 0 & 13 \\
\hline
\end{tabular}

These latter findings were considered to be artefacts of the pattern coefficient (see Discussion).

\section{Reproducibility of results}

Discrepancies between the data of Goodfellow \& Alderson (1977) and those from the present study were assessed. Gordona aurantiaca strain N663 was included in both studies; the test error between these duplicate strains was approximately $6.5 \%$. In the present study, G. aurantiaca strains M290 and N663 were duplicates with an $S_{S M}$ value of $97.9 \%$ corresponding to a probability of error, $P$, of $1 \%$.

\section{Differentiation between Gordona aurantiaca and the other taxa}

The percentages of positive responses to each test within the clusters and subclusters are shown in Tables 3 and 4. Fourteen characters were selected as having the greatest resolving power for the differentiation of the four major clusters (Table 5).

\section{Lipid analyses}

Thin-layer chromatographic analysis of whole-organism methanolysates of the $G$. aurantiaca strains showed the presence of two major components (Fig. 2). The most mobile fractions $\left(R_{F}>0.6\right)$ corresponded to methyl esters of long-chain non-hydroxylated fatty acids and the least mobile components were similar in their migration to methyl esters of mycolic acids (Minnikin et al., 1975). The supposed mycolic esters from G. aurantiaca strains were more mobile on t.l.c. than were the methyl mycolates from the Rhodococcus strains and showed similar mobility to the least polar mycolic ester from Mycobacterium avium.

Gas chromatographic analysis of the long-chain fatty acid esters of $G$. aurantiaca strains 


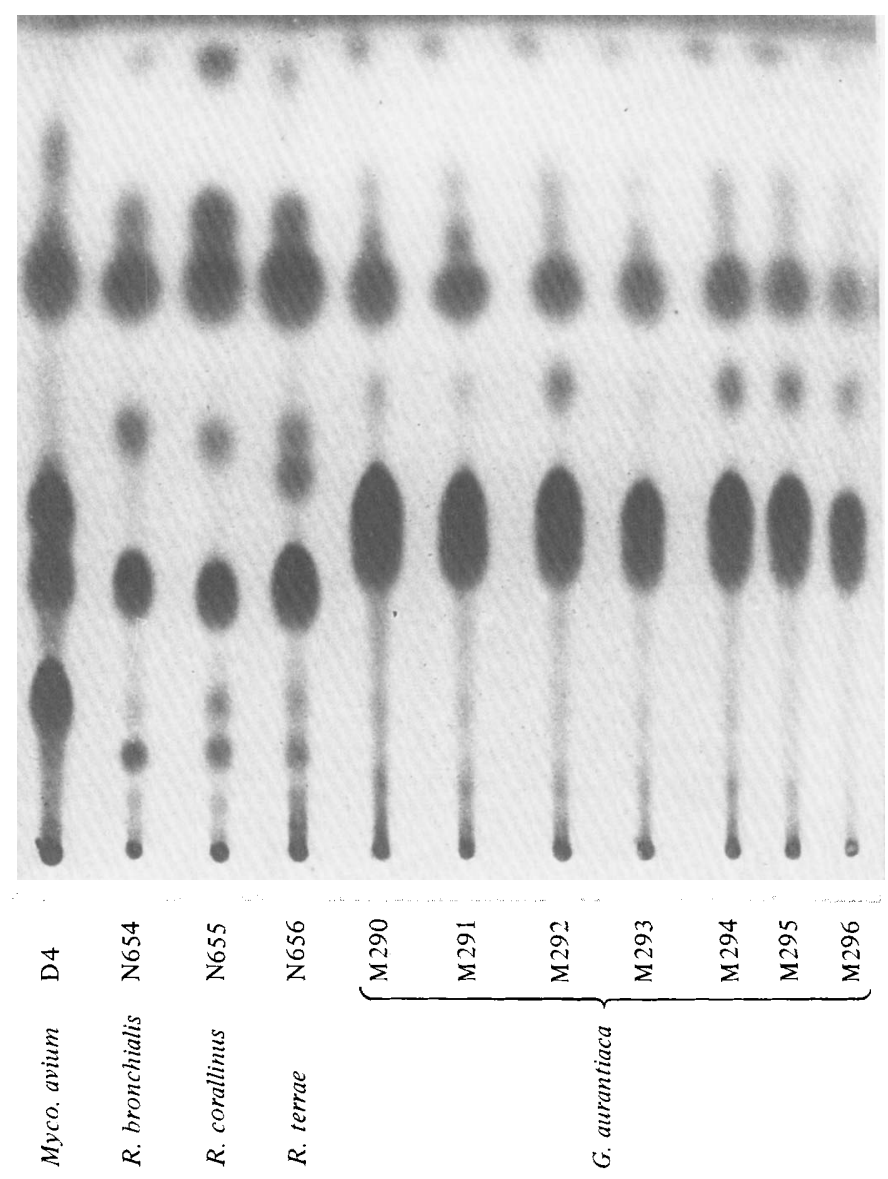

Fig. 2. Thin-layer chromatography of whole-organism methanolysates of Gordona aurantiaca and related organisms.

(Table 6) revealed major proportions of straight-chain saturated and unsaturated acids and a component co-chromatographing with methyl 10-methyloctadecanoate (tuberculostearate) from Mycobacterium avium. Methyl tuberculostearate was not separated from methyl octadecenoate on the polar (Silar 5CP) stationary phase.

The long-chain components from $G$. aurantiaca strains which were chromatographically similar to mycolic esters (Fig. 2) all gave essentially the same results on pyrolysis gas chromatography and mass spectrometry. The mycolic ester from G. aurantiaca M290, for example, produced, on pyrolysis gas chromatography, four peaks of comparable intensity corresponding to straight-chain $\mathrm{C}_{20}$ and $\mathrm{C}_{22}$ saturated and mono-unsaturated esters. Mass spectrometry (Etémadi, 1967; Alshamaony et al., 1976a) of the same ester showed mediumsized peaks at $m / e 326$ and 354 corresponding to the $\mathrm{C}_{20}$ and $\mathrm{C}_{22}$ saturated acids released on pyrolysis. No significant fragments corresponding to the unsaturated components $(\mathrm{m} / \mathrm{e} 324$ and 352) were observed; loss of the elements of methanol (32 mass units) apparently gave rise to medium-sized peaks at $m / e 292$ and 320 . A complex series of fragments corresponding to aldehydes formed by pyrolysis was seen at the following $m / e$ values (main component in bold type; figures in parentheses specify the number of carbon atoms and degree of unsaturation $): 684\left(\mathrm{C}_{48: 2}\right), 686\left(\mathrm{C}_{48: 1}\right), 710\left(\mathrm{C}_{50: 3}\right), 712\left(\mathrm{C}_{50: 2}\right), 734\left(\mathrm{C}_{52: 5}\right), 736\left(\mathrm{C}_{52: 4}\right), 738$ $\left(\mathrm{C}_{52: 3}\right), 740\left(\mathrm{C}_{52: 2}\right), 760\left(\mathrm{C}_{54: 6}\right), 762\left(\mathrm{C}_{54: 5}\right), 764\left(\mathrm{C}_{54: 4}\right), 766\left(\mathrm{C}_{54: 3}\right), 788\left(\mathrm{C}_{56: 6}\right)$ and 790 
Table 6. Fatty acid composition of Gordona aurantiaca strains, determined by gas chromatography of methyl esters on polar and non-polar columns

\section{Strain}

G. aurantiaca $\mathrm{M} 290$

G. aurantiaca $\mathrm{M} 291$

G. aurantiaca $\mathrm{M} 292$

G. aurantiaca M293

G. aurantiaca $\mathrm{M} 294$

G. aurantiaca $\mathrm{M} 295$

G. aurantiaca $\mathrm{M} 296$
Relative percentages $(w / w)$ of fatty acids*

\begin{tabular}{|c|c|c|c|c|c|c|c|c|c|}
\hline $14: 0$ & $15: 0$ & $14: 1$ & $16: 0$ & $16: 1$ & $17: 0$ & $17: 1$ & $18: 0$ & $18: 1$ & $\mathrm{t}-19$ \\
\hline $1 \cdot 3$ & $\cdots$ & 一 & $65 \cdot 7$ & $2 \cdot 3$ & 一 & $\ldots$ & 14.9 & $6 \cdot 0$ & \\
\hline $4 \cdot 0$ & $1 \cdot 0$ & 0.9 & $41 \cdot 9$ & $4 \cdot 3$ & 0.4 & 0.4 & $12 \cdot 5$ & $33 \cdot 6$ & \\
\hline $4 \cdot 6$ & - & - & $43 \cdot 4$ & $7 \cdot 0$ & - & - & $4 \cdot 4$ & $24 \cdot 3$ & 16 \\
\hline $2 \cdot 2$ & - & - & $34 \cdot 5$ & $6 \cdot 5$ & 一 & 一 & $17 \cdot 7$ & $18 \cdot 2$ & 20 \\
\hline $3 \cdot 0$ & 0.5 & - & $41 \cdot 2$ & $5 \cdot 5$ & - & - & $3 \cdot 4$ & $25 \cdot 9$ & 20 \\
\hline $3 \cdot 0$ & 0.2 & - & $39 \cdot 5$ & $6 \cdot 4$ & - & - & $3 \cdot 3$ & $27 \cdot 2$ & 20 \\
\hline $3 \cdot 4$ & - & 一 & $40 \cdot 0$ & 5.6 & - & - & $3 \cdot 5$ & $22 \cdot 6$ & 24 \\
\hline
\end{tabular}

* The number preceding the colon indicates the number of carbon atoms and the number after the colon indicates the number of double bonds; $t-19$ denotes 10-methyloctadecanoic (tuberculostearic) acid.

Table 7. Peaks corresponding to molecular ions in the mass spectra of menaquinones isolated from strains of Gordona aurantiaca

The main component of each series is denoted by +++ , any components greater than $50 \%$ of the main peak by ++ and all other significant components by + .

Menaquinone isopr
$m / e$
G. aurantiaca $\mathrm{M} 290$
G. aurantiaca $\mathrm{M} 291$
G. aurantiaca $\mathrm{M} 292$
G. aurantiaca $\mathrm{M} 293$
G. aurantiaca $\mathrm{M} 294$
G. aurantiaca $\mathrm{M} 295$
G. aurantiaca $\mathrm{M} 296$

$\begin{array}{cc}\text { MK-7 } & \text { MK-8 } \\ 648 & 716 \\ + & + \\ + & ++ \\ + & + \\ + & + \\ + & + \\ + & + \\ + & +\end{array}$

MK-9
784
+++
+++
+++
+++
+++
+++
+++

$\left(\mathrm{C}_{56: 5}\right)$. In the higher mass range, fragments corresponding to anhydromycolates, formed by elimination of a molecule of water, were found at $m / e ~ 992\left(\mathrm{C}_{68: 2}\right), 994\left(\mathrm{C}_{68: 1}\right), 1020$ $\left(\mathrm{C}_{70: 2}\right), 1042\left(\mathrm{C}_{72: 5}\right), 1044\left(\mathrm{C}_{72: 4}\right), 1046\left(\mathrm{C}_{72: 3}\right), 1048\left(\mathrm{C}_{72: 2}\right), 1070\left(\mathrm{C}_{74: 5}\right)$ and $1072\left(\mathrm{C}_{74: 4}\right)$.

Extracts of the test strains contained menaquinones which co-chromatographed on t.l.c. with vitamin $\mathrm{K}$. The most significant peak in the spectra occurred at $\mathrm{m} / \mathrm{e} 784$ corresponding to an unsaturated menaquinone with nine isoprene units, abbreviated as MK-9; smaller peaks at $m / e$ 648, 716 and 852 correspond to the minor components MK-7, MK-8 and MK-10 (Table 7).

\section{DISCUSSION}

Consistency between classifications based on different taxonomic techniques and methods is a pre-requisite for a stable taxonomy. Thus, numerical taxonomy can establish clusters whose robustness can be tested using different similarity coefficients and clustering algorithms (Austin \& Colwell, 1977), while chemotaxonomy seeks to highlight stable and discontinuously distributed characters that can be used as markers in identification.

In the present study, the G. aurantiaca strains formed a distinct cluster with all of the similarity coefficients and algorithms tested and, with few exceptions, the numerical classification of the other strains confirmed previous findings (Goodfellow \& Alderson, 1977). The effect of the exclusion of the 80 rhodococci examined in the earlier analyses was to reduce the tightness of some of the Rhodococcus subclusters established using the two clustering algorithms. The rhodococci included in the present study were selected to represent the whole range of variation found in the Rhodococcus taxon (Goodfellow \& Alderson, 1977), some being taken from the edges of subclusters thereby increasing the 
likelihood of peripheral members joining neighbouring subclusters in analyses based on a smaller sample of strains. This sampling problem was evident in the case of the Rhodococcus rhodochrous subcluster (1A) which had been defined by 49 strains (Goodfellow \& Alderson, 1977) of which only 10 were included in the present study; not all of these strains fell into a well defined subcluster in all of the numerical analyses.

The clustering of Mycobacterium borstelense (M89) and Brevibacterium linens (c40) with the $G$. aurantiaca strains in the pattern difference analysis is considered to be a consequence of the very large difference in vigour between these organisms. Thus, while the G. aurantiaca strains gave some 55 positive test responses, $M$. borstelense was coded for only 22 positive characters. The pattern difference coefficient calculates the product of the number of tests for which one organism gives a positive response and the other gives a negative one and the number for the reciprocal situation. Where the many positive responses of the vigorous organism coincide with the few of the less vigorous one, this product will be small giving an artificially small pattern difference. This masking effect on the pattern difference coefficient can be detected by comparing the relative numbers of positive tests given by each strain and confirmed by reference to the $\mathrm{S}$ values calculated for the $S_{S M}$ or $S_{J}$ coefficients.

In light of these considerations and the agreement between the various numerical analyses, the Gordona aurantiaca cluster is considered to be a distinct and robust grouping, equal in rank to the clusters corresponding to the genera Mycobacterium, Nocardia and Rhodococcus. There was sufficient consistency within clusters and differences between them for some characters to be provisionally weighted for identification (Table 5). Neither G. aurantiaca nor any other of the test strains showed a high overall similarity with the single strain of Brevibacterium linens.

The type strain of $G$. aurantiaca contains meso-diaminopimelic acid, arabinose and galactose in its walls (I.J. Bousfield, personal communication) and the taxon can, therefore, be provisionally added to the list of genera with a wall chemotype IV (Lechevalier, 1976; Goodfellow \& Minnikin, 1977). All of the G. aurantiaca strains contained characteristic highly unsaturated mycolic acids centred around $C_{70}$ which released $C_{20}$ and $C_{22}$ straightchain saturated and unsaturated acid derivatives on pyrolysis. Further detailed studies are needed before the exact structures of these mycolic acids can be established but the present data distinguish them from previously described acids. The mycolic acids from mycobacteria usually release $\mathrm{C}_{22}$ to $\mathrm{C}_{26}$ completely saturated acids on pyrolysis (Lechevalier et al., 1973); they are complex mixtures of acids having other oxygen functions in addition to the hydroxy acid unit and, to date, have never been found to contain more than two points of unsaturation in the molecule (Etémadi, 1967; Minnikin et al., 1975). Mycolic acids from true corynebacteria, nocardiae, rhodococci and related organisms release, on pyrolysis, acids in the range $C_{12}$ to $C_{18}$ (Lechevalier et al., 1973) and, in general, contain less than 70 carbon atoms (Minnikin \& Goodfellow, 1976). Unsaturation in the chain in 2-position of mycolates is also unusual but has been found in the mycolic acids from Nocardia amarae (Lechevalier \& Lechevalier, 1974) and certain other individual strains (Minnikin \& Goodfellow, 1976). The non-hydroxylated fatty acid composition of $G$. aurantiaca strains, containing straight-chain saturated and unsaturated acids and tuberculostearic acid, is similar to that of mycolic acid-containing taxa such as Mycobacterium, Nocardia and Rhodococcus (Kroppenstedt \& Kützner, 1976, 1978).

The presence of fully unsaturated menaquinones having nine isoprene units (MK-9) distinguishes $G$. aurantiaca strains from other mycolic acid-containing taxa which usually have dihydrogenated menaquinones (Yamada et al., 1976; Collins et al., 1977). The polar lipids of the type strain of $G$. aurantiaca, examined previously (Minnikin et al., 1977), were similar in general pattern to those of a variety of other mycolic acid-containing bacteria, containing significant amounts of diphosphatidylglycerol, phosphatidylethanolamine, phosphatidylinositol and mono- and diacylated phosphatidylinositol mannosides. The presence of phosphatidylethanolamine does, however, distinguish G. aurantiaca 
strains from corynebacteria, and Rhodococcus bronchialis, R. ruber and R. terrae, all formerly labelled Gordona, were found not to contain diacylated phosphatidylinositol mannosides (Minnikin et al., 1977).

Thus G. aurantiaca resembles Mycobacterium, Nocardia and Rhodococcus on the basis of wall, fatty acid and polar lipid composition but, on evidence from numerical phenetic, isoprenoid quinone and mycolic acid analysis, can be clearly distinguished from them. The inclusion of all of the other Gordona species in the genus Rhodococcus (Goodfellow \& Alderson, 1977) makes the genus Gordona invalid and consequently a new taxonomic niche is required for G. aurantiaca. On balance, the evidence presently available favours raising the taxon to generic status but further studies on additional strains are required if such a proposal is to be made with confidence. Until these additional studies have been done the organisms should be provisionally named the 'aurantiaca' taxon.

The authors are indebted to Professor $M$. Tsukamura who kindly provided cultures (see Table 1), to Dr I. J. Bousfield for wall data, to J. R. Leece for help with the computation, and to A. Temple and P. Kelly for technical assistance and mass spectroscopy, respectively. This investigation was supported, in part, by Medical Research Council grant G974/522/S, M.D.C. gratefully acknowledges receipt of a Luccock Scholarship (Medical Scholarships and Research Committee, Faculty of Medicine, Newcastle upon Tyne) and L. A. was supported by the Calouste Gulbenkian Foundation and the University of Mosul, Iraq. Thanks are also due to $\mathrm{Mr} \mathrm{H}$. B. Lee, Central Veterinary Laboratory, Weybridge, for freeze-dried cells of $M$. avium.

\section{REFERENCES}

Alshamaony, L., Goodfellow, M. \& Minnikin, D. E. $(1976 a)$. Free mycolic acids as criteria in the classification of Nocardia and the 'rhodochrous' complex. Journal of General Microbiology 92, 188-199.

Alshamaony, L., Goodfellow, M., Minnikin, D. E. \& Mordarska, H. (1976b). Free mycolic acids as criteria in the classification of Gordona and the 'rhodochrous' complex. Journal of General Microbiology 92, 183-187.

Austin, B. \& Colwell, R. R. (1977). Evaluation of some coefficients for use in numerical taxonomy of microorganisms. International Journal of Systematic Bacteriology 27, 204-210.

Bousfield, I. J. \& Goodfellow, M. (1976). The 'rhodochrous' complex and its relationships with allied taxa. In The Biology of the Nocardiae, pp. 39-65. Edited by M. Goodfellow, G. H. Brownell \& J. A. Serrano. London: Academic Press.

Collins, M. D., Pirouz, T., Goodfellow, M. \& Minnikin, D. E. (1977). Distribution of menaquinones in actinomycetes and corynebacteria. Journal of General Microbiology 100, 221-230.

ETÉMADI, A. H. (1967). Corrélations structurales et biogénétiques des acides mycoliques en rapport avec la phylogenèse de quelques genres d'actinomycétales. Bulletin de la Société de chimie biologique 49, 695-706.

Goodfellow, M. (1971). Numerical taxonomy of some nocardioform bacteria. Journal of General Microbiology 69, 33-80.

Goodfellow, M. \& Alderson, G. (1977). The actinomycete-genus Rhodococcus: a home for the 'rhodochrous' complex. Journal of General Microbiology 100, 99-112.
Goodfellow, M. \& Minnikin, D. E. (1977). Nocardioform bacteria. Annual Review of Microbiology 31, 159-180.

Goodfellow, M., Fleming, A. \& Sackin, M. J. (1972). Numerical classification of 'Mycobacterium' rhodochrous and Runyon's group IV mycobacteria. International Journal of Systematic Bacteriology 22, 81-96.

Gordon, R. E. \& Miнm, J. M. (1962). Identification of Nocardia caviae (Erikson) nov.comb. Annals of the New York Academy of Sciences 98, 628-636.

Kroppenstedt, R. M. \& KütZner, H. J. (1976). Biochemical markers in the taxonomy of the Actinomycetales. Experientia 32, 318-319.

Kroppenstedt, R. M. \& KützNER, H. J. (1978). Biochemical taxonomy of some problem actinomycetes. In Nocardia and Streptomyces, pp. 125-133. Edited by M. Mordarski, W. Kuryłowicz \& J. Jeljaszewicz. Stuttgart: Gustav Fischer Verlag.

Lechevalier, M. P. (1976). The taxonomy of the genus Nocardia: some light at the end of the tunnel? In The Biology of the Nocardiae, pp. 1-38. Edited by M. Goodfellow, G. H. Brownell \& J. A. Serrano. London: Academic Press.

Lechevalier, M. P. \& Lechevalier, H. A. (1974). Nocardia amarae sp.nov., an actinomycete common in foaming activated sludge. International Journal of Systematic Bacteriology 24, 278-288.

Lechevalier, M. P., Lechevalier, H. \& Horan, A. C. (1973). Chemical characteristics and classification of nocardiae. Canadian Journal of Microbiology 19, 965-972.

Minnikin, D. E. \& Goodfellow, M. (1976). Lipid composition in the classification and identification of nocardiae and related taxa. In The Biology of 
the Nocardiae, pp. 160-219. Edited by M. Goodfellow, G. H. Brownell \& J. A. Serrano. London: Academic Press.

Minnikin, D. E., Alshamaony, L. \& Goodfellow, M. (1975). Differentiation of Mycobacterium, Nocardia, and related taxa by thin-layer chromatographic analysis of whole-organism methanolysates. Journal of General Microbiology 88, 200-204.

Minnikin, D. E., Patel, P. V., Alshamaony, L. \& Goodfellow, M. (1977). Polar lipid composition in the classification of Nocardia and related bacteria. International Journal of Systematic Bacteriology 27, 104-117.

Mordarska, H., Mordarski, M. \& Goodfellow, M. (1972). Chemotaxonomic characters and classification of some nocardioform bacteria. Journal of General Microbiology 71, 77-86.

Mordarski, M., Goodfellow, M., Szyba, K., Pulverer, G. \& TKacz, A. (1977). Classification of the 'rhodochrous' complex and allied taxa based upon deoxyribonucleic acid reassociation. International Journal of Systematic Bacteriology 27, 31-38.

SNEATH, P. H. A. (1957). The application of computers to taxonomy. Journal of General Microbiology 17, 201-226.

SNEATH, P. H. A. (1968). Vigour and pattern in taxonomy. Journal of General Microbiology 54, 1-11.

SNeATH, P. H. A. \& Sokal, R. R. (1973). Numerical Taxonomy. The Principles and Practice of Numerical Classification. San Francisco: W. H. Freeman.

Sokal, R. R. \& MicheneR, C. D. (1958). A statistical method for evaluating systematic relationships. Kansas University Science Bulletin 38, 1409-1438.
Tsukamura, M. (1971). Proposal of a new genus, Gordona, for slightly acid-fast organisms occurring in sputa of patients with pulmonary disease and in soil. Journal of General Microbiology 68, 15-26.

TsukamuRA, M. (1973). A taxonomic study of strains received as 'Mycobacterium' rhodochrous. Description of Gordona rhodochroa (Zopf; Overbeck; Gordon \& Mihm) Tsukamura comb. nov. Japanese Journal of Microbiology 17, 189-197.

Tsukamura, M. (1974). A further numerical taxonomic study of the rhodochrous group. Japanese Journal of Microbiology 18, 37-44.

Tsukamura, M. (1975). Numerical analysis of the relationship between Mycobacterium, rhodochrous group and Nocardia by use of hypothetical median organisms. International Journal of Systematic Bacteriology 25, 329-335.

Tsukamura, M. \& Mizuno, S. (1971). A new species Gordona aurantiaca occurring in sputa of patients with pulmonary disease. Kekkaku 46, 93-98.

Tsukamura, M., Mizuno, S. \& Murata, H. (1975). Numerical taxonomy study of the taxonomic position of Nocardia rubra reclassified as Gordona lentifragmenta Tsukamura nom.nov. International Journal of Systematic Bacteriology 25, 377-382.

WisharT, D. (1968). A Fortran II Program for Numerical Taxonomy. St Andrews: University of St Andrews.

Yamada, Y., Inouye, G., Tahara, Y. \& Kondo, K. (1976). The menaquinone system in the classification of coryneform and nocardioform bacteria and related organisms. Journal of General and Applied Microbiology 22, 203-214. 